\title{
Evaluation of injury-related under-five mortality in Turkey between 2014-2017
}

\author{
Nilgün Çaylan ${ }^{1 \oplus}$, Sıddıka Songül Yalçın ${ }^{2 \oplus}$, Başak Tezel $^{1 \oplus}$, Şirin Aydınn ${ }^{1 \oplus}$, \\ Önder Özen ${ }^{1 \oplus}$, Meltem Şengelen ${ }^{3 \oplus}$, Banu Çakır ${ }^{3 \oplus}$ \\ ${ }^{1}$ Child and Adolescent Health Department, Ministry of Health, General Directorate of Public Health, Ankara; ${ }^{2}$ Department of \\ Pediatrics, Division of Social Pediatrics and ${ }^{3}$ Department of Public Health, Hacettepe University Faculty of Medicine, Ankara, Turkey.
}

\begin{abstract}
Background. Injury is the most common cause of preventable morbidity and mortality among children. The aim of this study was to determine the epidemiological characteristics and trends of injury-related mortality in children under five and to provide evidence for future preventive strategies.
\end{abstract}

Methods. Our study was designed as a descriptive cross-sectional study. National under-five mortality data from the Death Notification System database, entered between January 1st, 2014, and December 31th, 2017, was included in the study.

Results. Among all under-five deaths registered in the system, 2,560 injury-related death cases were included in the study. Overall, deaths related to injuries accounted for $4.1 \%$ of all deaths in children under five years old. Of all injury deaths, $59.9 \%$ of cases were male, $52.7 \%$ occurred at home or its close vicinity, and $80.3 \%$ were children aged 12-59 months. Injury-related under-five deaths were mainly attributed to traffic injuries (36.5\%), falls $(12.0 \%)$, and suffocation (10.2\%). Traffic injuries were the most common cause of injury-related deaths both in infants 0-11 months and children 12-59 months old. The second and third most common causes of injury-related deaths among infants 0-11 months were suffocation and falls, while these were falls and drowning in children aged 12-59 months, respectively. The injury-related under-five mortality rate dropped from 11.3 per hundred thousand in 2014 to 9.1 in 2017. Causes of all unintentional injury-related deaths were associated with season except for other unintentional injuries and exposure to mechanical forces $(\mathrm{p}<0.001)$.

Conclusions. The injury-related mortality rate among children under five years declined from 2014 to 2017, however it is still high. To prevent injuries in children under five, it is important to raise awareness and increase the supervision of children by their caregivers. At the national level, multisectorial cooperation with a holistic approach will be of key importance.

Key words: injury, mortality, under-five, children, Turkey.

Injury is the most common cause of preventable morbidity and mortality among children in every country in the world. Injury is defined as intentional or unintentional acute exposure of the human body to thermal, mechanical, electrical, or chemical energy exceeding the limits of physiological tolerance, or deprivation

$凶$ Nilgün Çaylan

nilgun.caylan@gmail.com

Revised 23rd December 2019, revised 16th March 2020, 9th June 2020, accepted 24th June 2020. of the human body from vital elements, such as oxygen and heat. ${ }^{1}$ Every year more than 5 million people die as a result of injuries, accounting for approximately $9.0 \%$ of worldwide deaths. ${ }^{1,2}$ It is estimated that, for every child death caused by an injury, there are 129 hospital admissions, 1,635 emergency service visits, and thousands of primary care appointments. ${ }^{3}$ Most survivors of injuries are subject to temporary or permanent disability, and injuries are responsible for approximately $6.0 \%$ of all disability adjusted life years (DALY). ${ }^{2}$ In Turkey, when all age groups are taken into consideration, $4.5 \%$ of all deaths, 
$5.3 \%$ of hospitalizations, and $9.0 \%$ of disease burden are due to injuries. ${ }^{4}$

Globally, the child mortality rate has decreased by approximately half over the past 25 years, mainly due to the decline in infectious diseases. ${ }^{5,6}$ However, the decline in injuryrelated mortality rate has been relatively slower. Therefore, deaths due to injuries in children have become increasingly prominent, especially in high income countries. ${ }^{1,7}, 8$ In 2013, accidental injuries were estimated to result in 324,000 deaths in children aged 1-59 months. ${ }^{7}$ According to the World Health Organization's (WHO) 2016 data, injuries account for $7.0 \%$ of deaths under the age of five years. ${ }^{5}$ Disparities also exist between the child injury mortality rates of developing and developed countries, with $95 \%$ of all child injury deaths occurring in developing countries. ${ }^{1,9}$

A detailed evaluation of the epidemiology of injury mortality is important for determining the priorities of preventative public health policies. The "Infant and Child Mortality Surveillance Program" and the "Child Safety Program" are both performed by the Child and Adolescent Health Department (CAHD) of the Ministry of Health $(\mathrm{MoH})$ in Turkey, and have been since 2007 and 2014, respectively. Although the epidemiology of injury-related mortality in children has already been studied in several regional studies ${ }^{10,11}$, there is no published study that assesses the injury-related deaths among children under-five at the national level. The aim of this study was to analyze epidemiologic characteristics and trends of injury-related under-five deaths between the years 2014 and 2017 in order to provide evidence for future preventive strategies.

\section{Material and Methods}

Our study was planned as a descriptive crosssectional study. Data on under-five deaths were obtained from the Death Notification System (DNS) database. Since 2013, all deaths are registered in the DNS database. In this database, along with the deceased's personal information, the socio-demographic characteristics, death type, a forensic outcome, and injury information sections are requested to be filled in. Whether the death had a natural cause or is a forensic case, and if the death was due to a communicable or non-communicable disease are asked in the death type section. In instances where forensic case is selected, the forensic outcome area is mandatory. The forensic outcome area includes suicide, homicide, traffic accident, occupational accident, other accidents, and ongoing forensic research options, and helps to determine the intentional status of the death. If an autopsy is performed, the result of the autopsy is recorded in the system by the forensic practitioner. When a death occurred as a result of injury, the injury information section should also be filled in. This section includes information such as the date of injury, place of injury, and whether it was a work accident. All the diseases and conditions contributing to a person's death are also recorded chronologically in the system, using the International Classification of Statistical Disease Classification (ICD-10) codes. In the system, a stepwise causal chain is used in reporting the causes of death. The "main cause" of death is defined as the oldest of the series of diseases that led to the death, and is thus the disease that initiated the death process. The final cause of death is defined as the most recent disease in the series of diseases leading to the death. According to the Infant and Child Mortality Surveillance Program workflows, "Provincial Infant Mortality Monitoring Committees" also review all infant (0-11 months) deaths in detail. The final electronic reports of these committees are sent to DNS by the end of each month.

All child deaths under 60 months (born alive with any gestational week) in DNS between January 1st, 2014, and December 31st, 2017, were included in the study. Among all deaths, the deaths having any of the injury diagnosis codes as their main cause of death were identified by the working group. Injuries due to birth trauma were excluded from the study. A data sheet for evaluating each injury mortality case was filled 
out including: 1) date of birth, 2) date of injury, 3) place of injury, 4) date of death, 5) age, 6) gender, 7) province of residence, 8 ) diagnostic ICD-10 codes, 9) death type, 10) forensic outcome, and 11) autopsy result (if performed).

The causes of injury were classified using the ICD-10 codes determined in the recently published WHO guidelines and used in previous studies by the working group. ${ }^{12-16}$ Based on WHO guidelines, the injury-related deaths were divided into intentional and unintentional injury subheadings. ${ }^{12,13}$ The intention status of an injury was determined by evaluating the above mentioned death type, forensic outcome, injury information section data, and ICD-10 codes together. The intentional injuries subheading included: self-harm (X60-X84, Y87.0), interpersonal violence (homicide/assault) (X85-Y09, Y87.1), and collective violence and legal intervention (Y35-Y36, Y89, Y89.1). The unintentional injuries subheading included: traffic injuries (V01-V99), poisonings (X40-X49), falls (W00-W19), burns (X00-X19), drownings (W65-74), exposures to mechanical forces (W20-W38, W40-W43, W45, W46, W49-W52), natural disasters (X33-X39), suffocation (W75-W76, W78-W80, W83-W84), and other unintentional injuries (rest of V01Y98). "Exposures to mechanical forces" included: contact with falling or thrown objects, contact with sharp objects (knives, swords, wedges, glass, etc.), gunshot wounds, contact with machines (agriculture, industry, and electrical appliances), and explosions (gas cylinder, boiler, pressure equipment, bombs, etc.). The subtitle "other unintentional injuries" was used to evaluate exposures to electric current, contact with animals and toxic animals (bite, attack), exposure to heat, cold, or sun, freezing, staying in an oxygen-free environment, food and water deprivation, poverty, accident sequelae, surgical treatment and medical care complications, and cases due to the side effects of exposure to biological substances, drugs, and vaccines. ${ }^{12,13}$ In our study, injury-related mortality cases having poorly-defined causes and/or unknown intent due to ongoing forensic research were collected under the third subheading of "other, ungrouped" by the working group.

In calculating cause-specific mortality rates, age-specific population numbers referring to the relevant years were used. The risk of injury varies according to different stages of development, therefore, under-five injury mortality cases were stratified into two groups by age: 0-11 months (infants) and 12-59 months. ${ }^{17}$

The study was approved by the Hacettepe University, Non-Interventional Clinical Research Ethics Committee (2019/13-20) and official permission was obtained from the General Directorate of Public Health (official permission date and number: March 20, 2019; 67414668-020-E.300) for sharing and analysis of the DNS data. Informed consent was obtained from parents before the registration of mortality information on the DNS database.

Data were analyzed using SPSS ver. 23.0 statistical software package. Analyses included arithmetic mean and standard deviation for continuous variables and frequency and percent distributions for categorical variables. Chisquare test was used for group comparisons. Type I error was pre-set at 0.05 for all analyses.

\section{Results}

Based on DNS data, between 2014 and 2017, a total of 62,192 under-five deaths occurred, and 2,560 of all under-five deaths were due to injuries. Overall, deaths related to injuries accounted for $4.1 \%$ of all under-five deaths in children (Table I). Of all injury deaths, 1,534 (59.9\%) cases were male and the female/male ratio was $1 / 1.5$. While $19.7 \%(n=505)$ of the cases were in the $0-11$ months old age group, $80.3 \%(n=2055)$ were in the 12-59 months old age group. In the majority of cases, the injury occurred at home or in the close vicinity $(52.7 \%)$. When seasonal variations in injury-related deaths were examined, it was found that deaths were highest in the summer $(n=963,37.6 \%)$ and lowest in the winter $(n=338$, $13.2 \%$ ) (Table I). 
Table I. Basic information of injury-related under five mortality in Turkey, 2014-2017 (N=2560).

\begin{tabular}{|c|c|c|c|c|c|c|}
\hline & & 2014 & 2015 & 2016 & 2017 & Total \\
\hline \multicolumn{2}{|c|}{ Total number of under-five death $(\mathrm{N})$} & 16536 & 16108 & 15475 & 14073 & 62192 \\
\hline \multicolumn{2}{|c|}{ Death caused by injury $N(\%)^{*}$} & $709(4.3)$ & $632(3.9)$ & $629(4.1)$ & $590(4.2)$ & $2560(4.1)$ \\
\hline Age & $0-11$ months & $144(20.3)$ & $143(22.6)$ & $104(16.5)$ & $114(19.3)$ & 505 (19.7) \\
\hline$N(\%)^{* *}$ & $12-59$ months & $565(79.7)$ & $489(77.4)$ & $525(83.5)$ & $476(80.7)$ & $2055(80.3)$ \\
\hline Gender & Male & $432(60.9)$ & $374(59.2)$ & $379(60.3)$ & $349(59.2)$ & $1534(59.9)$ \\
\hline $\mathrm{N}(\%)^{* *}$ & Female & $277(39.1)$ & $258(40.8)$ & $250(39.7)$ & $241(40.8)$ & $1026(40.1)$ \\
\hline Place of injury & Home or its close vicinity & $363(51.2)$ & $338(53.5)$ & 333 (52.9) & $316(53.6)$ & $1350(52.7)$ \\
\hline \multirow[t]{2}{*}{$\mathrm{N}(\%)^{* *}$} & Areas away from the home & $346(48.8)$ & $294(46.5)$ & $296(47.1)$ & $274(46.4)$ & $1210(47.3)$ \\
\hline & Spring & 196 (27.6) & $156(24.7)$ & $171(27.2)$ & $142(24.1)$ & $665(26.0)$ \\
\hline Season & Summer & 259 (36.5) & $238(37.7)$ & $246(39.1)$ & $220(37.3)$ & 963 (37.6) \\
\hline \multirow[t]{2}{*}{$N(\%)^{* *}$} & Autumn & $163(23.0)$ & $163(25.8)$ & 135 (21.5) & $133(22.5)$ & $594(23.2)$ \\
\hline & Winter & $91(12.8)$ & 75 (11.9) & 77 (12.2) & $95(16.1)$ & 338 (13.2) \\
\hline
\end{tabular}

* Proportion of injury-related death numbers to total numbers of under-five deaths of relevant years.

${ }^{* *}$ Column percentage

The injury-related under-five mortality rate dropped from 11.3 per hundred thousand in 2014 to 9.1 per hundred thousand in 2017 (Fig. 1). The largest contributors to this change were the declines in the rates of traffic injuries (from 4.4 to 3.1$)$, drownings (1.1 to 0.7$)$, and falls (1.5 to 1.2) (Fig. 2).

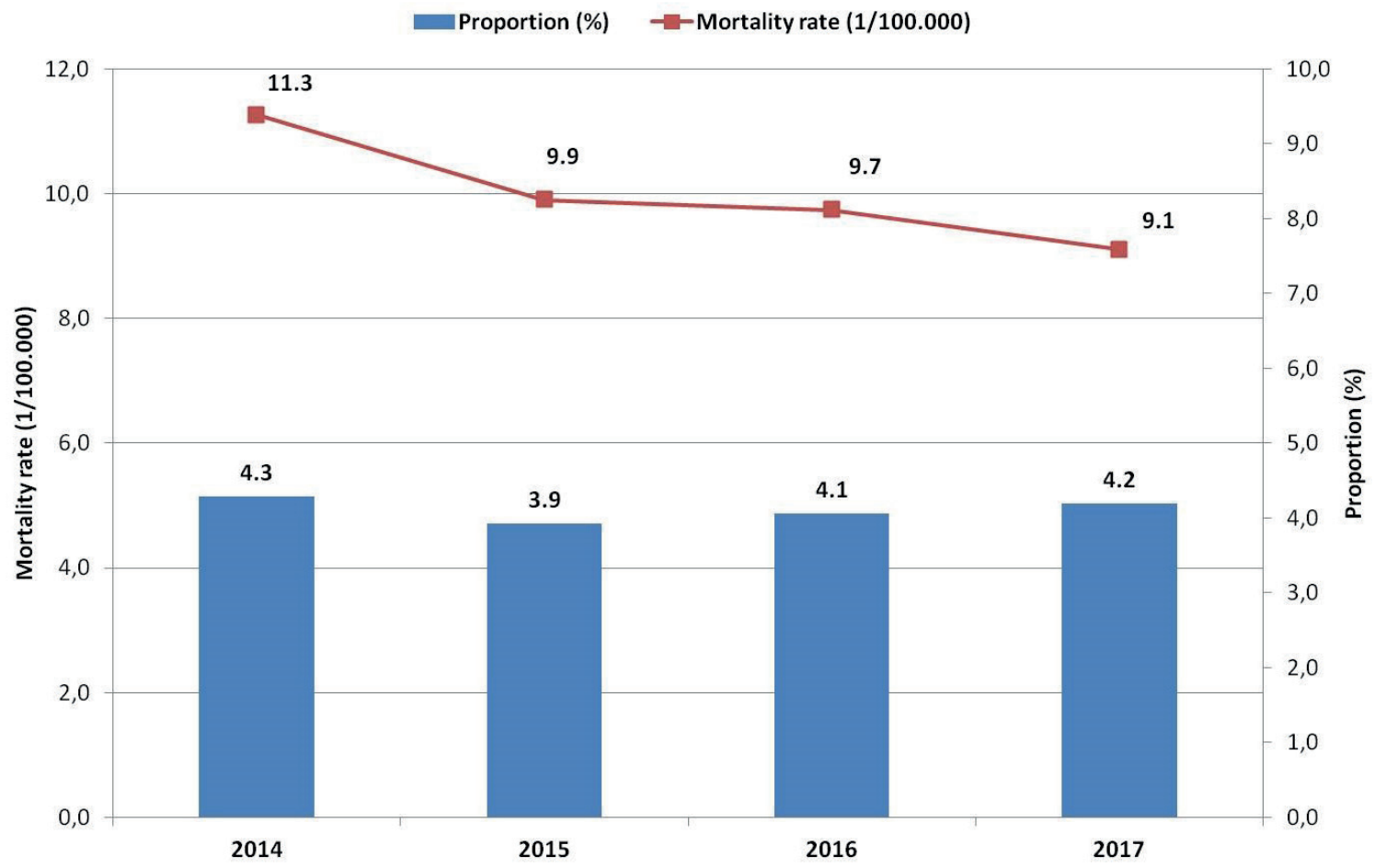

Fig. 1. Injury related mortality rates and the proportion of injury-related deaths to all cause of deaths in underfive children in Turkey, 2014-2017 (N=2560).

*Cause-specific mortality rates were calculated using the number of under-five populations of relevant years. 


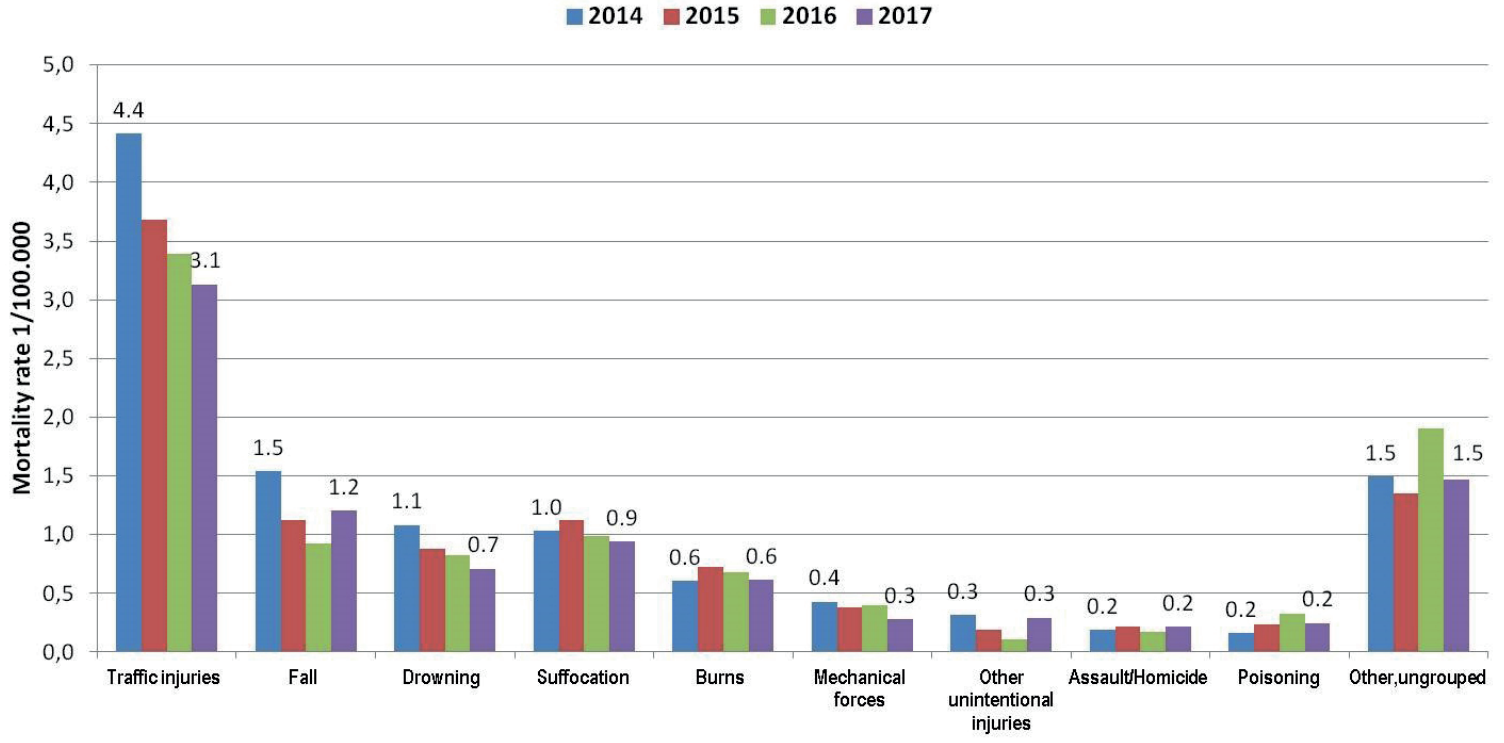

Fig. 2. Trends of mortality rates due to specific types of injury in children aged under-five in Turkey, 2014-2017 $(\mathrm{N}=2560)$.

*Cause-specific mortality rates were calculated using the number of under-five populations of relevant years.

Injury-related under-five deaths were mainly attributable to traffic injuries $(36.5 \%)$, falls $(12.0 \%)$, and suffocation (10.2\%) (Table II). The top cause of injury mortality was traffic injuries, both in infants and among children aged 12-59 months (35.6\% in infants; $36.7 \%$ in 12-59 months). Among infants, suffocation $(27.9 \%)$ and falls $(10.7 \%)$ were the second and third leading causes of injury mortality; among children aged 12-59 months old, falls (12.3\%) and drowning $(9.6 \%)$ were second and third, respectively (Table II). The other ungrouped cases category consisted of $15.5 \%$ of all underfive injury mortality cases. During the detailed evaluation, it was found that $96.0 \%$ of these cases were trauma cases in which the type of injury could not be determined. All injury-related mortality causes according to age groups are shown in order of frequency in Table II.

The distribution of causes of deaths due to unintentional injuries $(\mathrm{N}=2110)$ was further examined by gender, place of injury, and season (Table III). A gender difference was detected only in the case of drownings, which were more common in males $(\mathrm{p}=0.039)$. Traffic injuries and drownings were more common in areas away from the home $(\mathrm{p}<0.001)$, while the remainder of the unintentional injuries mostly occured at home or in close vicinity to it ( $p<0.001)$. All unintentional causes of injury, except for exposures to mechanical forces and other unintentional injuries, showed seasonal differences. Poisoning cases were more common in the winter ( $\mathrm{p}<0.001)$ (Table III). Detailed analysis of poisoning cases showed that $65.6 \%$ of all poisoning-related deaths were due to carbon monoxide intoxication.

\section{Discussion}

This is the first nationwide study in Turkey assessing the epidemiology and trends of injuryrelated mortality in children under five years old. The results of this study show that injuryrelated under-five mortality rates declined over the past four years. Injuries are important causes of deaths in children worldwide, and significant inequalities have been reported with respect to a country's level of development and income level..$^{1,8,9,14,18,19}$ In a study by Peden et al. ${ }^{1}$, the death rates due to unintentional injuries in children 1-4 years of age were reported to be 8.5 
Table II. Ranking of injury-related death causes by age groups, Turkey, 2014-2017.

\begin{tabular}{llll}
\hline Rank & 0-11 month (\%) (N=505) & 12-59 month (\%) (N=2055) & Under-five (\%) (N=2560) \\
\hline 1 & Traffic injuries (35.6) & Traffic injuries (36.7) & Traffic injuries (36.5) \\
2 & Suffocation (27.9) & Falls (12.3) & Falls (12.0) \\
3 & Falls (10.7) & Drowning (9.6) & Suffocation(10.2) \\
4 & Burns (6.5) & Burns (6.6) & Drowning (8.7) \\
5 & Drowning (5.0) & Suffocation (5.9) & Burns (6.6) \\
6 & Assault/Homicide (3.4) & Mechanical forces (4.3) & Mechanical forces (3.7) \\
7 & Poisoning (2.0) & Poisoning (2.5) & Poisoning(2.4) \\
8 & Mechanical forces (1.4) & Other unintentional injury (2.5) & Other unintentional injury (2.3) \\
9 & Other unintentional injury (1.4) & Assault/Homicide (1.7) & Assault/Homicide (2.0) \\
& Other, ungrouped (6.1) & Other, ungrouped (17.9) & Other, ungrouped (15.5) \\
\hline
\end{tabular}

Table III. Comparison of unintentional injury related mortality causes by gender, place of injury and season (2014-2017) ( $\mathrm{N=2110).}$

\begin{tabular}{|c|c|c|c|c|c|c|c|c|c|c|c|}
\hline \multirow[b]{2}{*}{ Causes } & \multicolumn{2}{|c|}{ Gender } & \multirow[b]{2}{*}{$\begin{array}{c}\mathrm{p} \\
\text { value }\end{array}$} & \multicolumn{2}{|c|}{ Place of injury } & \multirow[b]{2}{*}{$\begin{array}{c}\mathrm{p} \\
\text { value }\end{array}$} & \multicolumn{4}{|c|}{ Season } & \multirow[b]{2}{*}{$\begin{array}{c}\mathrm{p} \\
\text { value }\end{array}$} \\
\hline & $\begin{array}{l}\text { Female } \\
(\mathrm{n}=845)\end{array}$ & $\begin{array}{c}\text { Male } \\
(\mathrm{n}=1265)\end{array}$ & & $\begin{array}{l}\text { Home or } \\
\text { its close } \\
\text { vicinity } \\
(\mathrm{n}=983)\end{array}$ & $\begin{array}{c}\text { Areas } \\
\text { away from } \\
\text { the home } \\
(\mathrm{n}=1127)\end{array}$ & & $\begin{array}{l}\text { Spring } \\
(\mathrm{n}=548)\end{array}$ & $\begin{array}{l}\text { Summer } \\
(\mathrm{n}=805)\end{array}$ & $\begin{array}{l}\text { Autumn } \\
(\mathrm{n}=479)\end{array}$ & $\begin{array}{l}\text { Winter } \\
(\mathrm{n}=278)\end{array}$ & \\
\hline $\begin{array}{l}\text { Traffic } \\
\text { injuries }(\%)^{*}\end{array}$ & 46.3 & 43.0 & 0.139 & 2.5 & 80.7 & $<0.001$ & $43.1^{\mathrm{a}}$ & $47.5^{\mathrm{a}}$ & $46.6^{\mathrm{a}}$ & $33.8^{\mathrm{b}}$ & 0.001 \\
\hline Fall (\%) & 14.2 & 14.8 & 0.711 & 29.6 & 1.4 & $<0.001$ & $14.6^{\mathrm{a}}$ & $18.4^{\mathrm{b}}$ & $14.0^{\mathrm{a}}$ & $4.3^{c}$ & $<0.001$ \\
\hline Suffocation & 12.8 & 12.2 & 0.679 & 25.7 & 0.8 & $<0.001$ & $12.2^{\mathrm{a}}$ & $7.8^{\mathrm{b}}$ & $13.4^{\mathrm{a}}$ & $24.5^{\mathrm{c}}$ & $<0.001$ \\
\hline $\begin{array}{l}\text { Drownings } \\
(\%)^{*}\end{array}$ & 8.9 & 11.7 & 0.039 & 8.2 & 12.6 & 0.001 & $11.7^{\mathrm{a}}$ & $11.3^{\mathrm{a}}$ & $11.1^{\mathrm{a}}$ & $5.4^{\mathrm{b}}$ & $<0.001$ \\
\hline Burns (\%)* & 8.8 & 7.4 & 0.270 & 16.2 & 0.8 & $<0.001$ & $9.1^{\mathrm{a}}$ & $5.1^{\mathrm{b}}$ & $6.3^{\mathrm{b}}$ & $16.9^{c}$ & $<0.001$ \\
\hline $\begin{array}{l}\text { Mechanical } \\
\text { forces }(\%)^{*}\end{array}$ & 4.3 & 4.7 & 0.661 & 6.8 & 2.5 & $<0.001$ & 4.9 & 4.0 & 4.6 & 5.0 & 0.815 \\
\hline $\begin{array}{l}\text { Poisonings } \\
(\%)^{*}\end{array}$ & 2.5 & 3.2 & 0.314 & 6.2 & 0.1 & $<0.001$ & $2.9^{\mathrm{a}}$ & $1.7^{\mathrm{a}}$ & $1.9^{\mathrm{a}}$ & $8.3^{\mathrm{b}}$ & $<0.001$ \\
\hline $\begin{array}{l}\text { Other } \\
\text { unintentional } \\
\text { injuries }(\%)^{*}\end{array}$ & 2.4 & 3.0 & 0.380 & 4.7 & 1.1 & $<0.001$ & 1.5 & 4.2 & 2.3 & 1.8 & 0.010 \\
\hline Total $(\%)^{*}$ & 100.0 & 100.0 & & 100.0 & 100.0 & & 100.0 & 100.0 & 100.0 & 100.0 & \\
\hline
\end{tabular}

* Column percentage

a,b,c Different letters are significant in the same row.

per hundred thousand in high-income countries and 49.6 per hundred thousand in low-middle income countries. Similar to our study results, death rates due to unintentional injuries have been reported to decrease in recent years, especially in high and middle-income countries worldwide. ${ }^{1,8,20}$ In a recent meta-analysis study by Adeloye et al. ${ }^{15}$ including publications between 1990 and 2018, the mortality rate due to injuries for children aged 0-4 years was reported to be $37.7(95 \% \mathrm{CI}=32.7-42.7)$ per hundred thousand globally.

Causes of injury-related mortality in childhood may vary between countries and regions. $8,9,15,16,18-20$ Our study showed that traffic injuries, falls, and suffocation were the top three causes of injury-related deaths among children 
younger than 5 years. In a study assessing global trends, traffic injuries, drownings, burns, suffocation, and falls were reported as the leading causes of injury-related death in underfive children. ${ }^{15}$ Similar to their results, we found that traffic injuries were the number one cause of mortality in both the 12-59 months old age group and in children under 5. However, in contrast to their results ${ }^{15}$, traffic injuries were also found to be the leading cause of injury related deaths in the infant age group in our study. Numerous regional studies in Turkey have examined the causes and characteristics of injuries in children. ${ }^{10,11,21-27}$ Although these studies differ in terms of study methodology and the age groups examined, traffic injuries and falls are reported as the top two causes of childhood injury. In a study from Diyarbakır assessing child deaths due to head injuries in 0-17 year olds, $55 \%$ of the fatal head traumas in the 0-6 age group resulted from falls and $34 \%$ resulted from traffic injuries. Considering all age groups, $81 \%$ of traffic injuries occurred outside the vehicle. ${ }^{10}$ In a study by Sever et al. ${ }^{21}$ evaluating forensic pediatric patients $(\leq 17$ years) admitted to the emergency department of a tertiary hospital, the most common reasons for admission in the trauma group were traffic injuries $(32.5 \%)$ and falls $(16.9 \%)$. In another hospital based retrospective study assessing 812 patients under the age of 15 suffering a traffic injury and who were admitted to the emergency department of a university hospital found that in-vehicle injuries formed the largest group $(59 \%) .{ }^{22}$ In addition, this study emphasized that, in the pediatric age group, traffic injuries involving a pedestrian and vehicle collision led to greater fatalities. ${ }^{22}$

In contrast to global trends and reports from other countries, in our study, falls was found to be the second most common cause of injuryrelated death among children younger than 5 years and children 12-59 months old. ${ }^{14-16}$ An earlier survey from Turkey determined the frequency and risk factors of serious injuries based on parental self-reports of children less than 10 years, admitted to an outpatient clinic of a university hospital. Their study reported the most common type of injury to be falls. ${ }^{24}$ Similarly, in an additional study on home injuries among children aged 0-6 years, falls was reported to be the most common cause. ${ }^{26}$ However, these studies were performed on injury cases that did not result in mortality, therefore the findings may not be directly comparable. ${ }^{24,26}$ These studies do, however, support the fact that falls are among the common causes of childhood injuries in Turkey. In a regional study assessing general characteristics of childhood falls over a period of 8 years in children aged younger than 14 years, the most common types of falls were from balconies $(38.5 \%)$, stairs $(22.5 \%)$, and walls $(8 \%){ }^{27}$ Of the victims, $64 \%$ were male and $56 \%$ were under 5 years of age. In their study, the most common injury type was found to be head injury $(50 \%)$ and the overall mortality rate was $3.6 \%$. The authors concluded that, in order to prevent falls from balconies, supervision by parents should be increased, new laws regarding barriers on balconies should be enacted, and campaigns including public education and media attention should be organised. ${ }^{27}$ Based on our study results, fall-related mortalities were common in both age groups, mainly occurred at home and/or its close vicinity, and happened in the summer time.

An important result of this study was that, although traffic injuries were the most common cause of injury-related death in children under five, the most important contributor to the decreasing tendency in the under-five injury mortality rate was the reduction in traffic injuries. In Turkey, in order to prevent traffic injuries road safety interventions are in force including the prohibition of speeding and drink-driving, regular traffic controls especially during public holidays, and mandatory use of child restraints for children 0-12 years old as well as the prohibition of children sitting in the front seat. These measures likely explain this decreasing trend in injury mortality rate..$^{22,28-30} \mathrm{In}$ order to achieve more effective results, existing interventions should be continued more strictly 
and audits should be increased. ${ }^{30}$

In our study, both injury-related mortality frequency and causes varied by age. This finding can be explained by differences in the developmental characteristics of different age groups. A general challenge in preventing pediatric injuries is the need to adapt interventions to the child's age and developmental stage. ${ }^{17}$ The most important developmental difference occurs during the period around 1 year of age, which is the transition period from infancy to toddlerhood. 9,17 Children from 1 to 4 years of age who are active and curious exhibit higher risk-taking behaviors compared to children under 1 year of age. The risk of injury among infants is mostly due to parental neglect or maltreatment, rather than mobility. ${ }^{9,14}$ In our study, the majority of suffocation-related deaths among children younger than 5 years occured in infancy, similar to previous reports. ${ }^{14,16}$ Additionally, intentional injuries (assault/homicide) were more common in the infant age group than the 1-4 years group, consistent with the literature. ${ }^{31}$ As children grow older, parents tend to reduce their amount of close supervision, leaving the children on their own and tending to believe their child can cope with the injury risks sufficiently. ${ }^{32}$ This knowledge may explain why injuries are more common in the 1-4 years age range compared to infants. Previous reports have also indicated that being the firstborn child and living in an overcrowded family both also increase the risk of injury. ${ }^{24,25,33}$

Another important result from our study is that the injury cases resulting in mortality showed seasonal variation. Traffic injuries, falls, and drownings were less common in winter, while suffocation, burns, and poisoning cases were more common in winter. In a recent study in China on the causes of death due to injuries in children under five years of age, seasonal relationships with some types of injuries were similarly reported. ${ }^{16}$ Seasonal variation has also been reported in previous regional studies in Turkey ${ }^{21,22}$ and, similar to our results, these studies found increased injury cases reported in the summer season. These seasonal relationships can provide some clues in determining preventive activities. The relationship between winter and the high rates of poisoning-related deaths can mainly be explained by carbon monoxide poisoning, pointing to a potential area for effective future interventions. The Ministry of Health initiated a "Carbon Monoxide Poisoning Prevention Program and Action Plan" in 2015. ${ }^{34}$ Our findings underline the importance of the need to sustain these programs in our country. Additionally, public announcements on media channels, meteorology warnings in the winter regarding the risk of carbon monoxide poisoning, etc. may all be used as potential interventions to decrease this type of injury.

Our analysis revealed that the majority of injuries leading to fatalities occurred either in the home or its close vicinity. Therefore, to prevent unintentional injuries, interventions should be comprised of arrangements to make these areas safer. Besides providing a safe home and play environment, adequate supervision of children by their caregivers is important to reduce injury risk. ${ }^{27,35-37}$ In one study, children who died of unintentional injuries under five years of age were shown to be under parental supervision 3.3 times less than children who survived. ${ }^{37}$ Therefore, it is important that parents and caregivers are informed about the causes and occurrence of injuries, as well as how they can be prevented..$^{35,36}$ Strong evidence shows that a number of interventions can save lives and mitigate the effects of injuries. Home visits, parent education against child abuse, neglect, and prevention, and counselling by health care professionals are all some of these preventive activities. ${ }^{29}$ As an action of our National Child Safety Program, counselling services are provided during the primary care follow-up visits to families with children under five regarding injury prevention. Also, primary health care professionals hold collective awareness activities for the public in Community Health Care Centers. 
Some strengths and limitations were present in our study. As we analysed the national underfive mortality data from the DNS database, our results may be generalizable to the community. The major limitation of this study was its secondary analysis nature, thus, all risk factors studied were restricted to those present in our national DNS. DNS, by itself, is prone to selfreport bias by parents or eyewitnesses to injury, and could be incomplete or biased due to the nature of the data collected and/or the person entering the data. It is important to increase awareness of physicians diagnosing the mortality and entering death certificates into DNS through in-service training programs, and periodic updating of such information would be of great benefit. Another specific limitation of our data is the high proportion of cases in the "other, ungrouped" subgroup consisting of the cases due to poorly defined causes and unknown intent due to ongoing forensic research. Almost every case in this group consisted of physical trauma. This situation was more frequent in the 12-59 months old age group. Ultimately, this limitation may lead to some causes of injury being under- or over-reported. There is also a possibility of missing cases of injury reflecting child abuse or neglect diagnoses. Inconsistent stories, a previous or subsequent history of child abuse, late presentation for medical care, and inappropriate child care should be warnings for child abuse and neglect cases. ${ }^{38,39}$ In the "Provincial Infant Death Monitoring Committees", the deaths occurring during infancy are examined in detail and sent to DNS as a report. A similar reporting system was planned to be launched for the 12-59 months death cases in 2020 . This regulation could make positive improvements to the injury-related mortality reporting of under-five children.

The epidemiologic characteristics of fatal childhood injuries vary according to the economic developmental level of a country, the special physical, environmental, and developmental conditions of residential settings, and time. ${ }^{1,8,9,14,15,18-20}$ Tailored intervention programs and effective implementation of such programs require robust evidence regarding the epidemiology of the injuries to be managed. Also, continuous monitoring of the impact of such activities is important for ensuring revisions, as needed. For this reason, the current study is crucial for determining the situation and planning future strategies. The decline in injuryrelated mortality rates among children underfive from 2014 to 2017 is promising. However, the mortality rates in Turkey are still higher than the rates in high-income countries. ${ }^{8,20}$ Thus, it should be kept in mind that injury remains among the leading and preventable causes of child mortality. A holistic approach, with wellcoordinated multisectorial cooperation will be of key importance when composing effective and comprehensive intervention programs to prevent injuries in children. ${ }^{40}$

\section{Acknowledgement}

The authors gratefully acknowledge the large quantity of health care professionals in the field who have contributed to data collection in the Infant and Child Mortality Surveillance System.

\section{REFERENCES}

1. World Health Organization. World report on child injury prevention. In: Peden M, Oyegbite K, OzanneSmith J, Hyder AA, Branche C, Rahman F, Rivara F, Bartolomeos K (eds). Geneva: World Health Organization, 2008.

2. World Health Organization. Injuries and violence: the facts. Geneva: World Health Organization, 2014.

3. Sethi D, Towner E, Vincenten J, Segui-Gomez M, Racioppi F. European report on child injury prevention. Copenhagen: World Health Organization Regional Office for Europe, 2008.

4. RepublicofTurkeyMinistryofHealth.HealthStatistics Yearbook 2017. Ankara, 2018 https://dosyasb.saglik. gov.tr/Eklenti/30148,ingilizcesiydijiv1pdf.pdf?0 (Accessed December 21, 2020).

5. United Nations Inter-agency Group for Child Mortality Estimation (UN IGME), Levels and Trends in Child Mortality: Report 2017. New York: United Nations Children's Fund, 2017. 
6. Kassebaum N, Kyu HH, Zoeckler L, et al; Global Burden of Disease Child and Adolescent Health Collaboration. Child and Adolescent Health From 1990 to 2015: findings from the global burden of diseases, injuries, and risk factors 2015 study. JAMA Pediatr 2017; 171: 573-592.

7. Liu L, Oza S, Hogan D, et al. Global, regional, and national causes of child mortality in 2000-13, with projections to inform post-2015 priorities: an updated systematic analysis. Lancet 2015; 385: 430440.

8. Mytton JA, Towner EM, Powell J, Pilkington PA, Gray S. Taking the long view: a systematic review reporting long-term perspectives on child unintentional injury. Inj Prev 2012; 18: 334-342.

9. Huang Y, Wu Y, Schwebel DC, Zhou L, Hu G. Disparities in under-five child injury mortality between developing and developed countries: 19902013. Int J Environ Res Public Health 2016; 13: 653.

10. Berber G, Arslan MM, Karanfil R, Çekin N. Diyarbakır'da kafa travmalarına bağlı çocuk ölümleri. Türkiye Klinikleri Adli Tıp ve Adli Bilimler Dergisi 2008; 5: 19-23.

11. Dirlik M, Bostancıoğlu B. Child drowning deaths in Aydin province, western Turkey, 2002-2012. Eur J Trauma Emerg Surg 2015; 41: 683-688.

12. Department of Information, Evidence and Research. WHO methods and data sources for global burden of disease estimates 2000-2016. Geneva: World Health Organization, 2018. https:/www.who.int/ healthinfo/global_burden_disease/GlobalDALY_ method_2000_2016.pdf (Accessed December 21, 2020).

13. Department of Evidence, Information and Research (WHO/Geneva) and Maternal Child Epidemiology Estimation (MCEE). MCEE- WHO methods and data sources for child causes of death 2000-2016. Geneva: World Health Organization, 2018. https:// www.who.int/healthinfo/global_burden_disease/ childcod_methods_2000_2016.pdf (Accessed December 21, 2020).

14. Xiang L, Wang K, Miao L, et al. Injury-related mortality among children younger than 5 years in China during 2009-2016: an analysis from national surveillance system. Inj Prev 2019; 25: 60-66.

15. Adeloye D, Bowman K, Chan KY, Patel S, Campbell H, Rudan I. Global and regional child deaths due to injuries: an assessment of the evidence. J Glob Health 2018; 8: 021104.

16. Lili X, Jian H, Liping L, Zhiyu L, Hua W. Epidemiology of injury-related death in children under 5 years of age in Hunan province, China, 2009-2014. PLoS One 2017; 12: e0168524.
17. Flavin MP, Dostaler SM, Simpson K, Brison RJ, Pickett W. Stages of development and injury patterns in the early years: a population-based analysis. BMC Public Health 2006; 6: 187.

18. Sengoelge M, Hasselberg M, Laflamme L. Child home injury mortality in Europe: a 16-country analysis. Eur J Public Health 2011; 21: 166-170.

19. Imamura JH, Troster EJ, Oliveira CA. What types of unintentional injuries kill our children? Do infants die of the same types of injuries? A systematic review. Clinics (Sao Paulo) 2012; 67: 1107-1116.

20. Jansson B, De Leon AP, Ahmed N, Jansson V. Why does Sweden have the lowest childhood injury mortality in the world? The roles of architecture and public pre-school services. J Public Health Policy 2006; 27: 146-165.

21. Sever M, Saz EU, Koşargelir M. Bir üçüncü basamak hastane acil servisine başvuran adli nitelikli çocuk hastaların değerlendirilmesi. Ulus Travma Acil Cerrahi Dergisi 2010; 16: 260-267.

22. Serinken M, Ozen M. Pediyatrik yaş grubunda trafik kazası sonucu oluşan yaralanmalar ve özellikleri. Ulus Travma Acil Cerrahi Dergisi 2011; 17: 243-247.

23. Işık HS, Gökyar A, Yıldız O, Bostancı U, Ozdemir C. Çocukluk çağı kafa travmaları, 851 olgunun retrospektif değerlendirilmesi: epidemiyolojik bir çalışma. Ulus Travma Acil Cerrahi Dergisi 2011; 17: 166-172.

24. İnce T, Yalçın SS, Yurdakök K. Çocukluk çağında ciddi kaza sıklığ 1 ve risk faktörleri. Çocuk Sağlığ 1 ve Hastalıkları Dergisi 2014; 57: 173-182.

25. İnanç DÇ, Baysal SU, Coşgun L, Taviloğlu K, Ünüvar E. Çocukluk çağı yaralanmalarında hazırlayıcı nedenler. Türk Pediatri Arşivi 2008; 43: 84-88.

26. Karatepe TU, Akış N. 0-6 yaş çocuklarda ev kazası geçirme sıklığı ve ilişkili faktörler. Uludağ Üniversitesi Tıp Fakültesi Dergisi 2013; 39: 165-168.

27. Bulut M, Koksal O, Korkmaz A, Turan M, Ozguc H. Childhood falls: characteristics, outcome, and comparison of the Injury Severity Score and New Injury Severity Score. Emerg Med J 2006; 23: 540-545.

28. World Health Organization. World report on road trafic injury prevention. Geneva: World Health Organization, 2004.

29. Sethi D, Racioppi F, Baumgarten I, Vida P. Injuries and violence in Europe: why they matter and what can be done. World Health Organization, 2006.

30. Gupta S, Hoe C, Özkan T, et al. Evaluation of a fiveyear Bloomberg Global Road Safety Program in Turkey. Public Health 2017; 144S: S45-S56. 
31. Pearson J, Stone DH. Pattern of injury mortality by age-group in children aged 0-14 years in Scotland, 2002-2006, and its implications for prevention. BMC Pediatr 2009; 9: 26.

32. Guilfoyle SM, Karazsia BT, Langkamp DL, Wildman BG. Supervision to prevent childhood unintentional injury: developmental knowledge and self-efficacy count. J Child Health Care 2012; 16: 141-152.

33. Aydoğdu ZA, Ateş E, Set T. Assessment of mothers' measures against home accidents for 0-6-year-old children. Turk Pediatri Ars 2019; 54: 149-156.

34. T.C. Sağlık Bakanlığı. Türkiye Halk Sağlığı Kurumu. Türkiye Karbonmonoksit Zehirlenmelerinin Önlenmesi Programı ve Eylem Planı (2015-2018). https://hsgm.saglik.gov.tr/depo/birimler/cevresagligi/2-ced/karbonmonoksit-zehirlenmesi/ Turkiye_Karbonmonoksit_Zehirlenmelerinin_ Onlenmesi_Programi_ve_Eylem_Plani_2016.pdf (Accessed December 21, 2020).

35. İnce T, Yalçın SS, Yurdakök K. Parents' attitudes and adherence to unintentional injury prevention measures in Ankara, Turkey. Balkan Med J 2017; 34: 335-342.
36. Kendrick D, Mulvaney CA, Ye L, Stevens T, Mytton JA, Stewart-Brown S. Parenting interventions for the prevention of unintentional injuries in childhood. Cochrane Database Syst Rev 2013: CD006020.

37. Khatlani K, Alonge O, Rahman A, et al. Caregiver supervision practices and risk of childhood unintentional injury mortality in Bangladesh. Int J Environ Res Public Health 2017; 14: 515.

38. Sorenson SB, Peterson JG. Traumatic child death and documented maltreatment history, Los Angeles. Am J Public Health 1994; 84: 623-627.

39. Kemp AM, Mott AM, Sibert JR. Accidents and child abuse in bathtub submersions. Arch Dis Child 1994; 70: $435-438$.

40. Scholtes B, Schröder-Bäck P, Förster K, MacKay M, Vincenten J, Brand H. Multi-sectoral action for child safety-a European study exploring implicated sectors. Eur J Public Health 2017; 27: 512-518. 